\title{
ORTAÇAĞ MÜSLÜMAN DEVLETLERINDE HAYVANAT BAHÇELERI
}

\author{
Ömer TOKUŞ*
}

\begin{abstract}
$\ddot{\mathbf{O z}}$
Ortaçağ toplumunda yaşam tarzının gereği olarak geçimini sağlamak, eğlenmek, spor yapmak veya savaşlar için hazırlıklı olmak gibi sebeplerden dolayı avcılık ilgi görmüştür. Sıradan insanlar için geçim kaynağı olan av ve avcılık hükümdarlar ve ileri gelen devlet adamları için de hobiye dönüşmüştür. Bu sebepten Emevî halifesi Yezîd b. Muaviye'den itibaren, avlanmak için çeşitli av hayvanlarının toplandığı ve bu hayvanların ihtiyaçlarını karşılamak için de görevlilerin tayin edildiği görülmektedir. Bunların yanı sıra yöneticilerin eğlence maksadıyla bazı hayvanları sarayda yetiştirdikleri ve bazen de özel alanlarda yarıştırdıkları olmuştur. Özellikle de sarayda yetiştirilen ve zaman zaman at yarışlarında dahi kullanılan Yezîd b. Muâviye'nin Ebû Kays adlı maymunu dikkate değer bir örnek olarak karşımıza çıkmaktadır. Nitekim avlanma ve eğlenme amacıyla kullanılan bu hayvanlar için hükümdarlar veya ileri gelen yöneticiler özel yapılar bina etmişlerdir. $\mathrm{Bu}$ çalışmada Ortaçağ Müslüman devletlerinde hükümdarlara ve üst düzey yöneticilere ait olan hayvanat bahçeleri şeklinde inşa edilen yapılara dair bazı örnekler sunulmuştur.
\end{abstract}

Anahtar Kelimeler: Ortaçağ, Av, Avcılık, Hayvanlar, Hayvanat Bahçeleri

\section{Abstract \\ Zoo in Medieval Muslim States}

In medieval society, hunting attracted interest for reasons such as earning a livelihood as a requirement of a lifestyle, having fun, playing sports, or being prepared for battles. Hunt and hunting, a source of livelihood for ordinary people, has also become a hobby for monarchs and dignitaries. For this reason, it is seen that various hunting animals were collected for hunting from the Umayyad Caliph Yazid b. Muawiyah and officials were appointed to meet the needs of these animals. In addition, rulers bred some animals in the palace for entertainment purposes and sometimes competed them in private areas. In particular, Yazid b. Muawiyah's monkey named Abu Qays, which was bred in the palace and used even in horse races from time to time, is a

\footnotetext{
${ }^{*}$ Doç. Dr. Bingöl Üniversitesi, Fen-Edebiyat Fakültesi, Tarih Bölümü, Bingöl.

E-posta: otokus@bingol.edu.tr. ORCID: 0000-0001-9788-8920

(Makale Gönderim Tarihi: 04.05.2021 - Makale Kabul Tarihi: 05.06.2021)
} 


\section{Ömer TOKUŞ}

notable example. Thus, for these animals used for hunting and entertainment, the rulers or dignitaries built special structures. In this study, some examples of structures built in the form of Zoos belonging to rulers and dignitaries in medieval Muslim states are presented.

Keywords: Medieval, Hunt, Hunting, Animals, Zoo

\section{Giriş}

Ortçağ Müslüman devletlerinde hayvanat bahçeleri için ( حيقة الحيوان/حدائق (الحيوان) el-Hayr (الحير), el-Hâ'ir (الحائر), el-Hâyir (الحاير) gibi kelimeler ile bunlardan çoğul olarak türetilen el-Hiyâr (الحيار), el-Hayran (الحيران) veya el-Havrân (الحوران) vibi kavramların kullanıldığı görülmektedir. Hare (حار) fiilinden türediği düşünülen bu kelimenin "suyun biriktiği ve döndüğü yer" anlamına geldiği ileri sürülmektedir. Mezkûr mekânın yağmur suyunun birikmesinden oluştuğu, bu esnada suyun etrafinda dönerek bir hazire yani depo vazifesi gördüğü için el-Hayr ve el-Hâ'ir şeklinde isimlendirildiği kaydedilmektedir. Bunların yanı sıra el-Hayr kelimesinin halk arasında kullanıldığg yani ammice olduğu bunun fasih lisandaki karşılığının ise el-Hâ'ir olduğu da iddia edilmektedir. Bu ifadelerden de el-Hayr'ın suyun depolandığı yer, yağmur suyunun biriktiği yer veya yağmur suyunun dışarı çıkacak bir mecra bulamadığı alçak yerlere karşılık geldiği anlaşılmaktadır ${ }^{1}$. Basra'da yağmur sularının biriktiği yerlerden biri olan Hâ'irü'l-Haccâc da ismini bu özelliğinden almıştır².

Nitekim vahşi yani yabanî hayvanların tutulduğu mahşer veya mahbes olarak niteleyebileceğimiz yapılar Hayrü'l-vahş (حيرالوحش) ya da Hayrü'l-vuhûş̧ (حيرالوحوش) şeklinde tavsif edilmiştir. Bu şekilde anılmaları sahrada yaşayan hayvanların inşa edilen sarayların yakınlarında bulunan söz konusu mekânlara doğru yönlendirilerek takip edilmeleri, ardından da hayvanların kendileri için hazırlanan bu alana girişlerinden sonra kapıların kapatılmasından kaynaklanıyordu. Böylece etrafı yüksek duvarlarla örülmüş bu yapıların içine hapsedilen hayvanlar çıkış yolu bulmak gayesiyle nereye gideceklerini bilmeden gezinmeye yani dolanmaya başlamaktaydılar. Hayvanların bu durumları suyun bir alanda veya hazirede (depoda) toplanmasına benzetildiğinden hayvanların tutuldukları bu yapılara mecazi olarak Hayrü'l-vahş denilmiştir ${ }^{3}$.

Şüphesiz İbn Miskeveyh'in ${ }^{4} 315$ (927-928) yılında yağmacıların Bağdat'a girerek Kasru's-Süreyyâ'yı yağmaladıklarına ve bitişikte bulunan el-Hâ'ir'deki yabani hayvanları da öldürüldüklerine dair kaydı da söz konusu yapının hayvanat bahçesi niteliği taşıdığına delalet etmektedir. Öte yandan onuncu asrın önemli şairlerinden biri olan Sanavberî'nin ${ }^{5}$ şiirlerinde Hayrü'l-vahş'a dair kaydı ile Yâkût el-Hamevî ${ }^{6}$ ve

\footnotetext{
${ }^{1}$ Bkz., el-Ferâhîdî t.y., cilt III, s.289; İbn Dureyd 1987, cilt I, s.526; İbn Dürüsteveyh 1998, 504; el-Ezherî 2001, cilt V, s.149; el-Cevherî 1987, cilt II, s.641; el-Himyerî 1999, cilt III, s.1639; İbn Hişâm 2003, 34; Yâkût el-Hamevî 1995, cilt II, s.327; İbn Manzûr 1414, cilt IV, s.423, 426.

2 el-Ezherî 2001, cilt V, s.149.

${ }^{3}$ Tûkân 1981, 42, 45.

${ }_{4}^{4}$ İbn Miskeveyh 1998, cilt V, s.230.

5 es-Sanavberî 1998, 54.

${ }^{6}$ Yâkût el-Hamevî 1995, cilt II, s.327.
} 
İbnü'l-Adîm'in ${ }^{7}$ Hıyârı Benî 'Abes ve Hıyârı Benî el-Ka'kâ'a gibi ifadeleri hayvanat bahçeleri için el-Hâ'ir, Hayrü'l-vahş ve Hıyâr gibi tabirlerin daha sıklıkla kullanıldığını kanıtlamaktadır. Söz konusu bu yapıların yanında tarımsal faaliyetlerin yapıldığı, değişik meyve ağaçlarının ekildiği bahçeler (bûstân), hayvanların su ihtiyaçlarının temin edildiği havuzlar (havd), sportif faaliyetlerin icra edildiği meydanlar, eğlence meclisleri, saray ve mescidler gibi daha başka mimari komplekslerin varlığı dikkat çekmektedir. $\mathrm{Bu}$ çalışmada ilk dönemlerde hayrü'l-vahş olarak nitelendirilen daha sonra bostan (bustân) olarak isimlendirilen hayvanat bahçeleri örnekleri veya buna benzer bazı yapılar üzerinde durulacaktır. Araştırmamızın sınırları, konunun hacmine bağlı olarak Emevîler ile başlayıp Türkiye Selçuklu Devleti'nin sonuna kadar uzanan süreci kapsamaktadir.

\section{Emevîler Dönemi}

Ortaçağ Müslüman devletlerinde Hayvanat Bahçelerinin ortaya çıkışına dair girişimlerin daha ziyade halife, emir veya ileri gelen devlet adamlarının avcılık ile iştigalleri ile ortaya çıktığı söylenebilir. Bu cümleden Cahiliye döneminden itibaren avcılık ile meşgul olan Arapların, avcılığı daha ziyade geçimlerini temin etme ve hayatlarını idame ettirmenin bir aracı veya savaşlara hazırlık amacıyla birer tatbikat olarak gördükleri ${ }^{8}$ anlaşılmaktadır. Bu avcılıkta ok ve yay gibi silahlarla kaplan, ceylan veya kuş avladıkları anlaşılan Arapların, Bizans, İranlılar ve Türkler ile karşılaştıktan sonra şahin, doğan, atmaca, çita, köpek ve tazı (kelâbizî) gibi hayvanları da avlanmakta kullanmaya başladıkları görülmektedir. Kevâsir, (ed-davârî) olarak nitelendirilen yırtıcı hayvanlar ile cevârih şeklinde adlandırılan av kuşlarının yaygın olduğu görülmektedir ${ }^{9}$. Savaş egzersizi ve spor olarak Hz. Peygamber (s.a.v) de avcılığı teşvik etmiştir. Hülefayi Râşidin ile de bu teşvikler devam etmiş ve bu gaye ile Hz. Ömer Kûfe valisinden at yarışları düzenlemesine dair talepte bulunmuştur ${ }^{10}$.

Emevîler ile birlikte halifelerin ilgilerinin de etkisiyle avcılığın hobiye dönüştüğü gözlemlenmektedir. Avcılığın yanı sıra halifelerin sosyal hayat içerisinde hobi olarak at yarışları için el-halbe (halbetü'l-hayl حلبة الخيل) olarak isimlendirilen hipodromlar inşa etmeleri aynı anda çok sayıda atın barındırılması zorunluluğunun da hayvanat bahçelerinin ortaya çıkışına etki ettiği söylenebilir ${ }^{11}$. Emevî halifesi Yezîd b. Muâviye'nin avcılığa ilgi duyduğu ve bu amaçla avda kullanmak maksadıyla yırtıcı kuş ve çıta gibi bazı av hayvanlarını beslediği kaynaklarımızda mevcuttur. Avcılığa düşkün olan Yezîd b. Muâviye'nin devamlı surette ava çıktığı, av köpeklerine bilezikler (halhal) taktırdığı, değerli kumaşlar giydirdiği ve her köpekle meşgul olan köleler görevlendirdiği malumumuzdur ${ }^{12}$. Bu yönüyle Me'sûdî ${ }^{13}$ Yezîd'i eğlence tutkunu, av

\footnotetext{
7 İbnü'l-Adîm t.y., cilt I, s.125, 251, 539.

${ }^{8}$ Ahsen 2019, 234-235.

${ }^{9}$ Özaydın 1991a, 101-104.

${ }^{10}$ Altınay 2006, 442.

11 İbn Abdirabbih 2021, cilt I, s. 164; Zeydan 2012, 797-798; Altınay 2006, 442.

12 İbnü't-T1ktaka 2016, 51-52.

${ }^{13}$ Me'sûdî 2005, cilt III, s.69.
} 


\section{Ömer TOKUŞ}

hayvanları, köpekler, maymunlar, çita ve şarap arkadaşlarına sahip olmakla tavsif etmektedir. Bunlara ilave olarak da Ebû Kays adında bir maymunu meclislerde bulundurduğunu ve yabani bir eşeğe bindirerek hipodromda yarıştırdığını söylemektedir. Emevîlerde maymun, köpek ve horoz gibi hayvanları toplayarak onlarla eğlenme geleneğini başlatanın da Yezîd $b$. Muâviye olduğu ileri sürülmektedir ${ }^{14}$.

Diğer Emevî halifelerinin de av ile meşguliyetleri bilinmekle birlikte bunun Yezîd dönemindeki gibi revaç bulmadığ 1 söylenebilir. Abdülmelik b. Mervân (685-705) ve Velîd b. Abdülmelik (705-715) dönemlerinde mimarî faaliyetlerin arttı̆̆ kaydedilmektedir. Halifeler inşa ettikleri yapılarda ziraî hayatı teşvik etmiş, ata binme ve avcılık gibi hobilerini icra edebilecekleri mahallere önem vermişlerdir. Çöl yaşamına özlem duydukları için Muaviye ve Abdülmelik dışındaki bütün Emevî halifelerinin Dımaşk dışında saraylarının bulunduğu ifade edilmektedir ${ }^{15}$. Karşılaştıkları yeni kültürün tesiri altında kalan Emevîler ekonomik refahın da etkisiyle eğlence ve dinlenme yeri olarak inşa ettikleri saraylarda lüks ve şatafat içinde yaşamlarını sürdürmüşlerdir ${ }^{16}$.

Atlara ilgi duyduğu kaydedilen Emevî halifesi Hişâm b. Abdülmelik'in el-Halbe yani hipodrom inşa ederek burada 4.000 kadar at barındırdığı anlaşılmaktadır ${ }^{17}$. Hişâm b. Abdülmelik'in (724-743) eğlenmek için hazırladığı her türden meyve ağaçlarının bulunduğu bir bustânı yani bahçesi de vardı ${ }^{18}$. Hişâm antik Palmyra şehri yakınlarında Kasrü'l-Hayri'l-Garbî ve Kasrü'l-Hayri'ş-Şârkî adında iki saray yaptırmıştır. Söz konusu bu saraylarda han, hamam, bahçe, cami, erzak depoları ve otlaklar bulunmaktaydı. Kasrü'l-Hayri'l-Garbî'nin sulama ihtiyacının yeraltından döşenen borular vasıtasıyla sağlandığı görülmektedir ${ }^{19}$. Buradaki arkeolojik çalışmalar Hişâm b. Abdülmelik' in inşa ettiği bu iki sarayın bitişiğinde hayvanat bahçesinin varlığına delalet ettiği ileri sürülmektedir. Şüphesiz mezkûr yapılar isimlerini de hayvanat bahçesi için kullanılan "hayr" sözcüğünden almıştır. Bu özelliklerinden dolayı söz konusu sarayların bitişiğinde yüksek duvarlarla örülü ve gelişmiş bir sulama sistemine sahip bu mekânlar Ortaçağ İslam toplumunda tespit edilebilen ilk hayvanat bahçesi örneklerinden biri olarak kabul edilmektedir ${ }^{20}$.

Halife Velîd b. Yezîd (743-744) de atlara düşkündü ve onları toplamayı severdi. Hişâm zamanında atı es-Sindî ile birlikte yarışlara katılırdı. Rûsâfe'de atlara binerek yarışlara katılan Velîd b. Yezîd, koşan bir attan diğerine atlayarak yarışmaktaydı. Velîd'in el-Halbe'de yani hipodromda 1000 kadar at topladığı kaydedilmektedir ${ }^{21}$. Öte yandan Velîd $b$. Yezîd'in ava tutkun olduğu da yazılmaktadır ${ }^{22}$. Av hayvanlarının

\footnotetext{
${ }^{14}$ Altınay 2006, 448.

${ }^{15}$ Erkoçoğlu 2017, 244-245.

${ }^{16}$ Hadad 2009, 1-8.

${ }^{17}$ Me'sûdî 2005, cilt III, s.195.

${ }^{18}$ Me'sûdî 2005, cilt III, s.200.

${ }^{19}$ Erkoçoğlu 2017, 249-251.

${ }^{20}$ Tûkân 1981, 45-46.

${ }^{21}$ Me'sûdî 2005, cilt III, s.208-210.

22 el-Belazürî 1996, cilt IX, s.166.
} 
beslenme ve barınmasını sağlamak için yer temin etme, av ile birlikte ele geçirilen ya da hediye olarak takdim edilen yabani hayvanlar ve yarış atları için hususi yapıların inşa edilmesi hayvanat bahçeleri tarzında bazı mekânların ortaya çıkmasına olanak sağlamış gözükmektedir.

\section{Abbâsîler Dönemi}

Avlanma, Abbâsîler ile halifelerin en gözde egzersizlerinden biri olma özelliğini taşımaya başlamış ve bu gaye ile özel olarak yetiştirilen kuşlar ve hayvanlar kullanılmıştır. Abbâsî halifelerinin bu eğilimlerinin spora ilgileri, zenginliğin artması, ve İranlılar ile yakın ilişkiler kurmaları ile açıklanabileceği ileri sürülmüştür ${ }^{23}$. Bizans ve Sâsânî kültürünün de tesiriyle Abbâsîler döneminde avcılığın önemini artırmasına paralel olarak Abbâsî halifeleri avcılıkta kullandıkları veya av esnasında canlı olarak ele geçirdikleri hayvanlar için özel barınaklar inşa etmeye başlamışlardır. Bu cümleden ilk Abbâsî halifesi Ebü'l-Abbâs es-Seffâh'ın (749-754) av partileri düzenleyerek şahin ve doğan gibi yırtıcı kuşlar ile köpek ve pars beslediği kaydedilmektedir. Öte yandan söz konusu hayvanların bakımı için görevliler tayin etmiştir ${ }^{24}$.

İkinci Abbâsî halifesi Ebû Cafer Mansur (754-775) da daha önce İran ile yapılan savaşlarda düşman ordularınca fillerin kullanıldığını görünce askerî seferlerde fillerden faydalanmış ve onlar için özel bir yer imar ettirmiştir ${ }^{25}$. Üçüncü Abbâsî halifesi Mehdî'nin (775-785) de ava düşkün olduğu ve ölümünün de bir rivayete göre av esnasında gerçekleştiği kaydedilmektedir ${ }^{26}$. Mehdî ve Hâdî’nin Emevî halifesi Velîd b. Yezîd gibi hareket halindeki atların üzerinden başka bir ata binmekte mahir oldukları hikâye edilmektedir ${ }^{27}$. Hârûn Reşîd (786-809) döneminde av merakının yanı sıra at yarışlarının da ilgi görmeye başlaması üzerine halbetü'l-hayl şeklinde isimlendirilen hipodromlar inşa edilmiştir ${ }^{28}$. Hârûn Reşîd'in kafeslerde aslan ve kaplan beslediği ve Bizans İmparatorundan 190 (805-806) yılında hediye olarak 12 doğan ve dört av köpeği aldığı da anlatılmaktadır ${ }^{29}$.

Emîn (809-813) halife olduktan sonra kuş, aslan ve başka vahşi hayvanları toplanmaya başlamıştır ${ }^{30}$. Buna dair Me'sûdî'nin ${ }^{31}$ naklettiği şu hadise dikkate değerdir. Buna göre; "Bir gün avcılar hile ile yakaladıkları büyük bir aslanı ahşap bir kafes içinde Emîn'e getirdiler. Bu sırada tahtında oturan Emîn, aslanın kafesten çıkarılmasını emretti. İtirazlara rağmen aslan salvverildi ve salonda bulunanlar korkudan çevreye dağlldılar. Hiçbir şey olmamış gibi tahtında oturan Emîn, kendisine doğru yaklaşan aslanın kulaklarından tuttuğu gibi firlattı. Bu esnada Emîn'in parmakları yerinden çıktı

\footnotetext{
${ }^{23}$ Ahsen 2019, 235.

${ }^{24}$ Yilmaz 2005, 257-258.

${ }^{25}$ Emin 2012, cilt VI, s. 112

${ }^{26}$ Me'sûdî 2005, cilt III, s.294-295; Bozkurt 2003, 377-379.

${ }^{27}$ Me'sûdî 2005, cilt III, s.208-210.

${ }^{28}$ Me'sûdî 2005, cilt III, s.342.

29 et-Taberî t.y., cilt VIII, s.508-509; Ahsen 2019, 236.

30 et-Taberî t.y., cilt VIII, s.508-509.

${ }^{31}$ Me'sûdî 2005, cilt III, s.369-370.
} 


\section{Ömer TOKUŞ}

ve getirilen bir çıkıkçı ile tedavi edildi. Ölen aslanın karnı yarıldığında aslanın korkudan ödünün (ciğer) koptuğu görülmüştü." Emîn'in balıklara karşı da özel bir hassasiyetinin olduğu söylenmektedir. Nitekim kardeşi Me'mûn ile girdiği taht kavgasında Bağdat'ta muhasara altına alınan Emîn'in bütün bu sıkıntılı gelişmelere rağmen sarayının ortasındaki bir havuzda pencereden Dicle Nehri'ni izlediği ve havuzunda küpe taktığı özel bir balığı ile ilgilendiği hikâye edilmektedir. Söz konusu havuzda Dicle'ye açılan ve içinde demir bir ağ bulunan bir kanal vardı. Nüveyrî̉ ${ }^{32}$ hayrü'l-vahş'ın yanında içki içen Emîn'in yanına şarkıcısı İbrahim'in ud ile geldiğini ifade etmektedir. Bu anlatıya "vahşi hayvanların şarkı söyleyen İbrahim'e yanaşarak boyunlarını uzattı̆̆ ve şarkı durduğunda da uzaklaştıklarını" eklemektedir. Nitekim Emîn ülkenin değişik yerlerinden topladığı farklı türlerden vahşi hayvanları, aslanları ve kuşları Bağdat'a getirtmekteydi ${ }^{33}$. Emîn ile yaptığ hilâfet mücadelesini kazanan Me'mûn (813-833) 819'da Bağdat'a geldiğinde inşa ettirdiği yarış alanları ve hayvanat bahçeleri ile şehri daha da büyütmüştür ${ }^{34}$.

Abbâsî halifelerinden Mutasım (833-842) da mimariye önem vermiş ve bu amaçla Me'sûdî'nin ${ }^{35}$ kaydına göre övgüye değer işler yapmıştır. Mutasım, Bağdat'ta yaşanan sorunlardan dolayı maiyetindeki Türkler için yeni bir şehir yapmaya karar vermiştir. Bu gaye ile Bağdat'ın kuzeyinde Dicle Nehri'nin sol kıyısında bulunan eski bir yerleşim yerini belirlemiştir. Veziri Ahmed b. Halid el-Kâtib'i göndererek 219'da (834) Sâmerrâ'nın mevkiini tespit eden halife, şehrin kurulacağı yerde Hristiyanlara ait bir kiliseyi ve yakınlardaki bir bahçeyi satın almıştır. Müteakiben inşasına karar verdiği kenti kurmak için 220'da (835) Kâtûl Nehri kıyısına gelerek çadır kurmuştur. Burası olası bir isyan esnasında karadan ve nehirden Bağdat'a ulaşımın suhuletle sağlanabileceği bu mekânda av yapmak için üç gün kalan Mutasım 221'de (836) şehrin temellerini attırmıştır ${ }^{36}$.

Mutasım, yoğun bir şekilde başlattığı imar faaliyetleri için farklı yerlerden ustalar ve işçiler getirtmiştir. Kendisi için bir saray yaptırarak diğer bölgelerden buraya ağaç ve fidanlar nakletmiştir. Her zanaat erbabına bir pazar kurdurup şehrin ulaşım ihtiyaçları için yol, geçit ve caddeler imar etmiştir. Ayrıca insanların faydalanacağı hayvanları ve malları buraya toplamıştı ${ }^{37}$. Mutasım, şehrin kurulmasından sonra Vasîf ve adamlarına "hayr" olarak isimlendirilen bölgeden sonraki kısmı ikta olarak vermiş̧ir. Öte yandan söz konusu yerde "hâ'irü'l-hayr" adında uzun bir duvar inşa edilmiştir ${ }^{38}$. Bunun yanı sıra şehirde "şâriü'l-hayr" ve "hayrü'l-cedîd" adında iki farklı mekânın adı da kaydedilmektedir. Türklerin ikamet ettiği bu caddede yıkılan bir duvarın yerine yenisinin inşa edildiğini söyleyen Ya'kûbî $^{39}$ duvarın arka tarafinda dişi ve erkek

\footnotetext{
${ }^{32}$ Nüveyrî 2004, cilt IV, s.198.

33 el-Halidî 2010, 110.

34 ed-Dûrî 1991, 427-428.

${ }^{35}$ Me'sûdî 2005, cilt IV, s.43.

${ }^{36}$ Me'sûdî 2005, cilt IV, s.49-50; Hasan t.y., 209-210; Demirci 2009, 70-71.

${ }^{37}$ Me'sûdî 2005, cilt IV, s.49-50.

${ }^{38}$ Ya'kûbî 2002, 41.

${ }^{39}$ Ya'kûbî 2002, 44-45.
} 
geyiklerin, yabani eşeklerin, tavşanların ve koyunların gezdikleri etrafı yüksek duvarlarla örülü bir yerden bahsetmektedir.

Dönemin görgü tanıklarından biri olan Câhiz'in ${ }^{40}$ Sâmerrâ'da "hayr" olarak adlandırılan mekândan söz etmesi de hayvanların tutulduğu ve barındığı bir yerin varlığına delalet etmektedir. Nitekim Ebü'l-Ferec el-İsfahânî ${ }^{41}$ (öl. 967) de Mutasım'ın istirahat vaktinde içki içerek şarkı dinlediği hayrü'l-vahş'1 zikretmektedir. Sâmerrâ' daki halifelik sarayının yanında büyük ve küçük olmak üzere iki adet mahzen bulunmaktayd1. Söz konusu mahzenlerden küçüğü aslanlar mahzeni şeklinde isimlendirilmişti. Sahrada kare şeklinde kazıldığı anlaşılan bu mahzenin derinliği 10, eni ise 21 metre idi. Ortasında dairevi bir havuzun bulunduğu bu alana intizamlı bir geçitten sarkıtılan iki merdiven ile inilip çıkılabilmekteydi. Öte yandan bu merdivenlerin giriş bölümlerinde duvarları alçıdan oyulmuş güzel resimlerden oluşan bir oda da vard $1^{42}$.

Mütevekkil (847-861) halife olduktan sonra Sâmerrâ'nın doğu tarafındaki yapılaşmayı genişletmeye karar vermiştir ve bu amaçla Mutasım'ın inşa ettiği hayvanat bahçesinin bir kısmını yıkarak buraya Bâbü'l-Hayr adında bir kapı eklemiştir ${ }^{43}$. Mütevekkil'in Sâmerrâ'nın doğu yönünde başlattığı bu mimarî faaliyetler ile etrafı surlar ile çevrilen hayvanat bahçesinin uzunluğu 30 km'ye kadar ulaşmıştır. Söz konusu hayvanat bahçesinde hayvanların bir kısmı dışarıda beslenirken bazıları da kafeslerde tutulmakta idiler. $\mathrm{Bu}$ hayvanat bahçesindeki hayvanların sayısının 2 bin civarında olduğu kaydedilmektedir ${ }^{44}$. Daha sonra halife olan Mühtedi (869-870) de mezkûr bahçede bulunan aslanlar ile dövüş horozları ve koçları öldürtmüştür ${ }^{45}$. Mutemid'in (870-892) 279'da (892) Bağdat'a dönmesinden sonra Sâmerrâ önemini yitirmeye başlamıştır ${ }^{46}$.

Halifelerin Bağdat'a dönüşlerinden sonra şehirde imar faaliyetlerinin yeniden canlılık kazanmaya başladığı görülmektedir. Bu cümleden Muktedir (908-932) Dicle Nehri kıyısında Nehrü'l-Mu'allâ'nın aşağı taraflarında meydan, fidanlık ve saraya bitişik bir hayrü'l-vahş yani hayvanat bahçesi inşa ettirmiştir. Bu hayvanat bahçesinin değişik hayvan türlerine ev sahipliği yaptığ Konstantin $^{48}$ (913-959) Muharrem 305'te (Haziran-Temmuz 917) halife Muktedir'e barış teklifinde bulunmak maksadıyla iki elçi göndermiştir ${ }^{49}$. Elçiler yanlarında 20 atlı ve değerli hediyeler ile Bağdat'a ulaştıklarında görkemli bir şekilde karşılanmışlardır ${ }^{50}$. Buradaki ikametleri esnasında elçilerin Bağdat'ın hayvanat bahçesini de ziyaret ettikleri

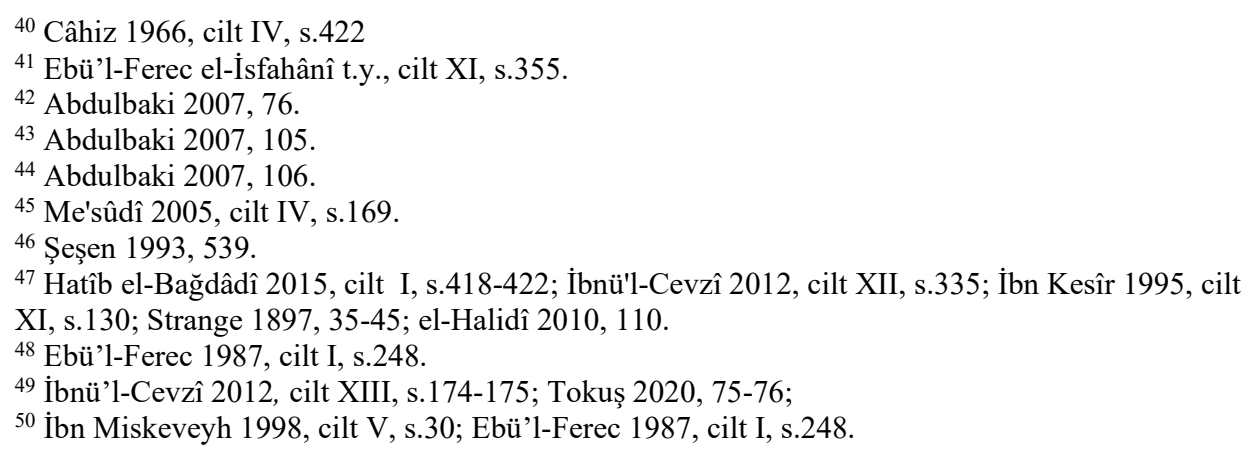




\section{Ömer TOKUŞ}

anlaşılmaktadır ${ }^{51}$. Şüphesiz Hilâl es-Sâbî'nin ${ }^{52}$ Abbâsî divanındaki 306 (918) yılına ait inek ve koyun gibi hayvanlar ile kuş ve vahşi hayvanların yem tedariki ile ilgili kayıtları hayvanat bahçesi hakkındaki en somut örneklerden biridir.

Me'sûdî, Muktedir dönemindeki hayvanat bahçeleri hakkında Muhammed b. Nasr'dan "Bir gün Muktedir'in huzuruna çıktım. Halife havuzun üzerine inşa ettirdiği sarayın sonunda bostana yani bahçeye bakan bir yerde oturuyordu. Burası Hîretu'lGazalân, Hazîretü'l-Kumârî̀ ve buna benzer alanlara nazır idi. Ben de dedim ki Ey Emîrül-mü'minin vallahi sen cennette oturuyorsun..." şeklinde bilgiler aktarmaktadir ${ }^{53}$. $\mathrm{Bu}$ kayıtlar sarayda ceylan ve kumruların bulunduğu iki hayvanat bahçesi ile adları zikredilmeyen daha başka bahçelere işaret etmektedir. Hilâl es-Sâbî ${ }^{54}$ de Daru'l-Azîze yani Dâru'l-Hilâfe'ye bitişik bir Hayr'dan bahsetmektedir. Ona göre burası, Muktedir'in hali ve geri dönüşü esnasındaki olaylardan ötürü zarar görmüştür.

Kâhir (929, 932-934) zamanında da Basra, Umman ve Hindistan'dan getirilen farklı türden ağaçların ekildiği bir narenciye bahçesi (Bustânu'n-Narenc) mevcut idi. Sarı ve kırmızı renkli meyvelerin bir yıldız gibi parladığı nitelendirilen bu bahçede çiçek, güzel kokulu bitkiler ve değişik türden fidanlar vardı. Öte yandan bu bahçenin ortasında farklı yörelerden getirilen kumru, filamingo (debâsî), karatavuk ve papağan gibi kuşlar da bulunuyordu. Halife gününün önemli bir kısmını çok sevdiği bu mahalde geçirirdi. Kâhir'den sonra halife olan Râzî (934-940) de burada ikamet etmeyi tercih etti ${ }^{55}$. Şüphesiz Râzî'nin hilafeti döneminde Kasru's-Süreyyâ'da bahçe ve gezinti yerleri önem kazanmıştır ${ }^{56}$.

Halife Müttakî ise (940-944) at yarışlarına önem verdiği için halbetü'l-hayl olarak isimlendirilen at yarışlarının düzenlendiği hipodrom inşa ettirmiştir ${ }^{57}$. Müttakî'nin halefi Müstekfî (944-946) de çıta ve şahinler ile avlanmaya meraklı olduğundan söz konusu avcı hayvanlar ve kuşlar ile bizzat ilgilenirdi. Bu merak ve ilgiden dolayı bildikleri ve gördükleri hayvanları sarayın yakınlarında inşa ettirdiği özel bir hayvanat bahçesinde tutmaya başlamıştı ${ }^{58}$. Büveyhîlerin 945 'te Bağdat'a hâkim olmasından sonra Büveyhî Emîri Adudüddevle de ihtişamını göstermek ve korku salmak için oturduğu meclisin çevresine zincirlerle bağlanmış aslanlar, filler ve kaplanlar bulundurmaktayd $1^{59}$.

Halifeler dışında devlet adamlarının da hayvanat bahçesi tarzında yapılar inşa ederek farklı türden hayvanları bir araya getirdikleri de görülmektedir. Şevval 272'de (Mart-Nisan 886) Bağdat'ta doğan ve Muktedir, Kâhir ve Râzî'ye vezirlik yapan Muhammed b. Ali b. el-Hüseyin b. Abdullah yani İbn Mukle'nin de hayvanat bahçesi

\footnotetext{
${ }^{51}$ Hatîb el-Bağdâdî 2015 cilt I, s.418-422.

52 Hilâl es-Sâbî t.y., 21-22.

${ }^{53}$ Me'sûdî 2005, cilt IV, s.268.

${ }^{54}$ Hilâl es-Sâbî t.y., 7 .

${ }^{55}$ Me'sûdî 2005, cilt IV, s.298-299; Emin 2012, 146-147.

${ }^{56}$ Me'sûdî 2005, cilt IV, s.288.

${ }^{57}$ Me'sûdî 2005, cilt IV, s.310-311.

58 Ahsen 2019, 236.

59 İbnü't-T1ktaka 2016, 31.
} 
şeklinde düzenlenen özel bir bahçeye sahip olduğu anlaşılmaktadır. Hurma dışında daha farklı ağaçları bünyesinde bulunduran bu bahçede (bustân) ibrişimden yani ipekten bir ağ ile çevrelenmiş alanda kuşların barınmaları, yumurtlamaları ve kuluçkaya yatmaları için özel bir yer bina edilmişti. Şevval 328'de (Temmuz-Ağustos 940) vefat eden İbn Mukle'nin bu mekânda kumru, filamingo (debbâsî), bülbül, papağan, Nube kuşları, karatavuk, tavus ve keklik gibi kara ve deniz kuşları ile ceylan, inek, deve kuşu, deve, yabani eşek gibi hayvanları beslediği söylenmektedir. Hayvanat bahçesinin duvarlarında kuşların kaldığ 1 ve kuluçkaya yattığı yuvalar da yapılmıştı. Söz konusu bu alan ipekten bir ağ ile örülmüştü ${ }^{60}$. Beş metre uzunluğunda 400 kadar hurma ağacının bulunduğu bahçenin ortasında Nehri Rasâs Kala'î geçiyordu. Uzunluğu 30, genişliği 20 zira olan bahçe Dâru's-Şecere'nin yanında idi ${ }^{61}$.

\section{Endülüs Emevî Devleti Dönemi}

I. Abdurrahman (Abdurrahman ed-Dâhil) (756-788) 756 yılında Kurtuba'yı ele geçirerek Endülüs Emevî Devleti'nin (756-1031) temellerini atmıştır. Bayındırlık faaliyetlerine öncelik veren I. Abdurrahman, yeni yapılar ve surlar inşa ederek Kurtuba'yı tahkim etmiştir. Öte yandan emîrlik sarayı ve bir mescid yaptıran I. Abdurrahman, er-Rusâfe adında yeni bir şehir kurmuştur. Dinlenmek için yapıldığ 1 anlaşılan bu şehre saray ve bahçe de ilave etmiştir. Oldukça geniş olduğu anlaşılan bu bahçeye Bilâdü'ş-Şâm ve daha başka bölgelerden getirttiği müteaddit ağaçlar ekmiştir. $\mathrm{Bu}$ faaliyetlere ek olarak Kurtuba'da kuş ve vahşi hayvanların barındıği bir mekândan da bahsedilmektedir ${ }^{62}$. Endülüs'te hayvanat bahçesine dair son bilgi III. Abdurrahman dönemine aittir. Özellikle X. yüzyılda Endülüs Emevîleri'nde artan imar faaliyetlerine paralel olarak yeni bazı hayvanat bahçelerine de tesadüf edilmektedir. Emevî Halifesi III. Abdurrahman (912-961) 325'te (936-937) cariyesi Zehra için Medinetü'z-Zehrâ adında bir şehir inşa ettirmiştir ${ }^{63}$. Bu yeni mekânda saraylar, bahçeler ve evler inşa eden III. Abdurrahman, vahşi hayvanlar için geniş bir avlu da yaptırmıştır. Çevresine çitler yerleştirilen bu bahçeye kuşlar için üzerinde ağ bulunan kulübeler de yerleştirilmişti ${ }^{64}$.

\section{Tolunoğulları Dönemi}

Modern çağın hayvanat bahçelerine benzer yapıların inşa edildiği en dikkate değer örnek Tolunoğullarına aittir. 868'de Misır'a hâkim olan Ahmed b. Tolun, yeni kurduğu el-Katâ'i'de imar faaliyetlerine girişerek mescid, değirmen, hamam, firın, çarşı/pazar gibi yapılar inşa ettirmiştir. Cadde ve sokakların birbirinden ayrıldığı bu yeni yerleşim alanında İbn Tolun bina ettiği sarayının bitişiğine savlecân (çevgan) oynamak için bir alan da eklemiştir. Mezkûr alanda bulunan sarayın kapılarından biri Bâbü'lSıbâ' yani Aslanlar Kapısı idi' ${ }^{65}$. Ahmed b. Tolun'un hususî bir hayvanat bahçesi

\footnotetext{
60 İbnü'l-Cevzî 2012, cilt XIII, s.393-396; Zehebî 1983, cilt XV, s.228.

61 el-Halidî 2010, 110.

${ }^{62}$ Makkarî 1968, cilt I, s.466-467, 523, 546; Hasan, t.y., 212-213; Y1ld1z 1988a, 147-150.

${ }^{63}$ Makkarî 1968, cilt I, s.523-527.

${ }^{64}$ Makkarî 1968, cilt I, s.578; Yıldız 1988b, 152-155.

65 el-Belevî t.y., 52-56.
} 


\section{Ömer TOKUŞ}

yaptırdığına dair somut bilgilerimiz bulunmamakla birlikte söz konusu saray kapısının Aslanlar ile isimlendirilmesi barındırılan aslanlar ile ilgili olduğunu düşündürmektedir. Ancak Ahmed b. Tolun'dan sonra emîrlik koltuğuna oturan oğlu Humâreveyh'in günümüz hayvanat bahçelerini andıran bir düzenlemeye giriştiği anlaşılmaktadır. Kaynağımız Makrîzîi ${ }^{66}$, Humâreveyh'in de el-Katâ'i'de yaşadığını imar faaliyetlerinde babasının izini takip ettiğini ifade etmektedir. Bu cümleden babasının inşa ettiği sarayın meydanını geniş bir bahçeye dönüştüren Humâreveyh, söz konusu mekânı botanik ve hayvanat bahçesi olarak tanzim etmiştir. Öncelikle bahçeye güzel kokulu çiçekler ve ağaçlar getirten emir, mezkûr bitki ve ağaçların sulanması için de farklı bir teknik geliştirmiştir. Hurma ağaçlarının gövdelerini sarı bakır ile kaplayan emir, bakırların ve hurma ağaçlarının arasına yerleştirdiği oluklar ile bahçedeki su sirkülasyonunu sağlamıştır. Söz konusu oluklardan akıtılan su ile hem ağaçların hem de buraya farklı şehirlerden ve bölgelerden getirilen kuşların ihtiyacı karşılanıyordu. Bahçe kumrular, filamingo ve Habeş tavuğu gibi farklı kuş türlerine ev sahipliği yapıyordu. Oluklardan akan sulardan içen kuşların kuluçkaya yatmaları için duvarların iç kısımlarına kova şeklinde yapılmış, zeminine otlar koyulmuş yuvalar inşa edilmişti. Botanik bahçede kuşların barınması için ağ şeklinde bir kafes bulunuyordu.

Bunların yanı sıra Humâreveyh'in sarayda aslanlar için de özel bir yer tahsis ettiği anlaşılmaktadır. Makrîzî ${ }^{67}$ yukarıda verilen bilgilerin devamında Humâreveyh'in Azâc'da her bir aslanın çifti ile kalabileceği özel hücreler yaptırdığını söylemektedir. Bu hücrelerin kapıları yukarından açılmakta idi ve birer küçük penceresi vardı. Hücreyi temizlemekle görevli olan kişi buradan içeriye giriyordu. Ayrıca her hücrenin yanında mermerden bir havuz vardi. Su, bu havuzlara bakırdan mamul kanallar vasitasiyla gelmekteydi. Hücrelerin önlerinde zemini kumla kaplı geniş bir avlu vardı. Seyis aslanı beslemek ve hücresini temizlemek isterse hücrenin üstündeki kapıyı kaldırıp aslana bağırırdı. Bu sesi duyan aslan da buradan ayrılarak geniş avluya giderdi. Bu sırada avluya açılan kapıyı kapatan seyis pencereden içeriye girerek zemini temizler, buradaki kumu değiştirir ve aslanı beslemek için yanında getirdiği eti keserek buraya koyardı. Ardından da buradaki havuzu temizleyerek su ile doldururdu. İşler bittikten sonra seyis hücreyi terk ederdi. Aslan da bunu öğrendiği için seyis hücrenin kapısını çektikten sonra içeriye giriyordu. Bu sırada aslan kendisi için hazırlanan eti yiyip su içerdi. Bunların yanı sıra aslanların kaldıkları hücrelerin kapıları aynı anda açılır ve aslanlar kendileri için hazırlanan bu sahaya girerek gezerlerdi. Akşama kadar burada kalan aslanlar daha sonra hücrelerine dönerlerdi.

Hayvanat bahçesi olarak düzenlenen bu yerlerde beslenen aslanlar Makrîzî'nin ${ }^{68}$ kayıtlarına göre ehlileştirilerek sarayda da bulundurulmaktaydı. Nitekim Humâreveyh'in gözleri mavi olduğu için Zurayk şeklinde isimlendirilen bir aslandan bahsedilmektedir. Humâreveyh ile yakınlık kurduğu anlaşılan bu aslan sarayda serbest bir şekilde gezer, emiri muhafaza eder ve sofra kurulduğunda emirin yanına gelirdi. Emir kendi eliyle aslanı beslerdi. Ayrıca Lebve adında ehlileştirilemeyen başka bir aslanın adının da öne

\footnotetext{
${ }^{66}$ Makrîzî 1998, cilt II, s.122-125; Mazaherî 1972, s.239; Ağırakça 1998, 349; Özkuyumcu 2012, 236.

${ }^{67}$ Makrîzî 1998, cilt II, s.126.

${ }^{68}$ Makrîzî 1998, cilt II, s.126-127.
} 
çıktığı görülmektedir. Kuşlar ve aslanlar dışında kaplan (nemr), fuhûd (leopar), fill, zürafa gibi daha başka hayvanlar için de özel hücrelerin inşa edildiği ve hayvanların bakımları için maaşılı kişilerin görevlendirdiği anlaşılmaktadır.

\section{Fâtımîler Dönemi}

Hayvanat bahçelerinin ortaya çıkışında halife, devlet adamları veya emîrlerin ilgilerinin önemli bir amil olduğunu yukarıda söylemiştik. Fâtımî halifesi el-Azîz (975996) ile İhşîdî devlet adamlarından biri olan ve Fâtımîlerin Mısır'ı almasından sonra kısa bir süre vezirlik görevini deruhte eden Ebü'l-Fazl İbnü'l-Furât yani İbn Hinzâbe de farklı türden hayvanları beslemek gibi bir hobiye sahip idi. Kısa bir süre Fâtımîlerin vezirliğini yapan ve Muiz'in Mısır'a gelişinden sonra 973'te azledilen Ebü'l-Fazl İbnü'Furât'ın yılanları ve haşeratı topladığı bir bahçesinden bahsedilmektedir. Söz konusu yılan ve sürüngenleri mermerden bir avluda, sepetlerde sergilemiş ve bunların bakımı için özel hizmetliler görevlendirmişti ${ }^{69}$.

Ebü'l-Fazl İbnü'l-Furât'ın yanı sıra av tutkusundan dolayı Fâtımî halifesi el-Azîz de sarayına birçok hayvan toplamıştı. Mezkûr hayvanlardan birinin de efsanevi bir kuş olan Anka olduğu ileri sürülmektedir. Sa‘îd'den Mısır'a geldiği iddia edilen Anka'nın çok büyük olduğu, gerdan ve çene altında da sakalı ve başının üzerinde de koruyucu halkası olduğu ifade edilmektedir. Değişik renklerden oluştuğu kaydedilen bu kuşun yaratılış yönüyle birden fazla kuşa benzediği söylenmektedir ${ }^{70}$. İbn Hallikân ${ }^{71}$ da Anka kuşunu tasvir ederken boğazının büyük, boynunun uzun, insana benzer bir yüzü ve her hayvana benzeyen bir yönü olduğunu ifade etmektedir. Öte yandan Ahmed b. Abdullah b. Ahmed el-Fergânî'nin Tarih'inde "Misır hâkimi el-Azîz'in kendisinden başkasının yanında bulunmayan ilginç hayvanları bir araya getirdiğini ve bunlardan birinin de Anka olduğunu" da eklemektedir.

Fâtımîler döneminde farklı türden hayvanları tedarik etmenin yollarından biri de hediyeleşme olmuştur. Bu eylem sayesinde himaye edilen hayvanların türlerini de tespit etmek mümkündür. Nitekim 384'te (994-995) Fâtımîlerin Mağrib'de bulunan Zîrî emîrlerine fil, eyerli ve gemli 100 at, katır, dişi deve (nakâ) ve Horasan develeri (Buhtî) gibi hayvanlar ile daha başka değerli hediyeler gönderdikleri anlaşılmaktadır ${ }^{72}$. Özellikle de Makrîzî'nin Fâtımî halifesi Zâhir (1021-1036) dönemi ile ilgili kayıtları önemli bilgiler vermektedir. Buna göre Nube'den (Nubya) 415'te (1024) köle ve cariyeler, abanoz ağacı ahşabı ile birlikte fil, zürafa gibi hayvanlar getirilmişti ${ }^{73}$. Aynı y1l içerisinde Cemaziyülahir 415'te (Ağustos-Eylül 1024) Zâhir'in talebi üzerine saraya papağanlar (bebeğa) ulaştırılmıştı ${ }^{74}$. Zâhir, Şevval 415'te (Aralık-Ocak 1024-1025) içinde fillerin bulunduğu altın ve gümüş saplı bayraklar ile davullar eşliğinde askerleri

\footnotetext{
${ }^{69}$ Mez 2014, 249; Bayrakdar 1998, 92; Aykaç 1999, 70-71.

70 Yâfi'î, 1997, cilt IV, s.27; Özaydin 1991, 346.

71 İbn Hallikân t.y., cilt III, s.101.

72 Makrîzî 2001, cilt I, s.313.

${ }^{73}$ Makrizi 2001, cilt II, s. 17.

${ }^{74}$ Makrîzî 2001, cilt II, s.21.
} 


\section{Ömer TOKUŞ}

ile birlikte gösteri yapmıșt1 ${ }^{75}$. Müteakiben Asvân'dan gönderilen 20 at, 80 Horasan devesi (buhtî), leopar (fehd), Nube koyunu, kuşlar, maymun ve fildişinden oluşan hediyeler 418'de (1027-1028) Zâhir'e takdim edilmiştir ${ }^{76}$.

Zîrî Emîri Muiz b. Bâdîs 424'te (1032) Zâhir'e dört aslan, 20 salûkiyye köpeği, birkaç leopar (fehd) hediye etmiştir ${ }^{77}$. Hayvanların bulunduğu bu tarz hediyeleşmelere dair son örneğimiz ise Fâtımî halifesi Müstansır (1036-1094) dönemine aittir. Reşid b. Zübeyr hediyelere dair yazmış olduğu eserinde Bizans İmparatorunun 444'te (10521053) Müstansır'a beyaz keklik, beyaz tavus kuşu, beyaz turna, beyaz bukîrât, beyaz sığırcık ve müzik eşliğinde oynayan bir ayı ile salûkiyye ve zebibîyye köpekleri gönderdiğini kaydetmektedir ${ }^{78}$. Takdim edilen hediyelerde bulunan hayvanların barınması için özel yapıların inşası elzemdir. Bu cümleden Fâtımîlerde hayvanat bahçesi tarzındaki mekânların kaynaklarımızda ismen kaydedilmese de varlığı bir ihtiyaç olarak karşımıza çıkmaktadır.

\section{Bâvendîler Dönemi}

Soylarını Sâsânîlere dayandıran Bâvendîler 45-750 (665-1349) yılları arasında "Keyûsiye", "İspehbediyye" ve "Kînhâriyye" adları ile farklı zaman aralıklarında üç şube halinde Taberistân'a (Mâzenderân) hâkim olan bir devlettir ${ }^{79}$. Bâvendîlerin İspehbediyye emîrlerinden Hüsâmüddevle Erdeşîr'e (1173-1206) kâtiplik yapan İbn İsfendiyâr, Târîh-i Taberistân adlı eserinde konumuz ile irtibatlı olarak kayda değer bir hayvanat bahçesinden bahsetmektedir. Çok sayıda saray inşa ettiği anlaşılan Hüsâmüddevle'nin Sârî'deki sarayın vasfinın mümkün olmadığını ifade eden İbn İsfendiyâr, özellikle Devletâbâd'da bulunan ve Bâdhâne şeklinde isimlendirilen sarayın tasvirini yapmaktadır. Sarayın yüzölçümünü veren yazar bir aslanın ağzından akıtılan su ile doldurulan bir havuzdan bahsetmektedir. Farklı yörelerden getirilen meyve ağaçlarının bulunduğu meydanın ortasında büyük havuz ve etrafında da güvercin, bülbül, kumru, papağan ve daha başka kuş türleri bulunduğunu söylemektedir. Söz konusu hayvanların ihtiyaçlarını karşılamak için içinde yem bulunan bir mahzen inşa edilmişti. Öte yandan sarayın başka bir köşesine yasemin, sümbül, menekşe gibi çiçekler ektirdi. Diğer bir tarafta ise yiyecekleri her zaman için hazır halde bulundurulan ceylan, geyik, tavşan, zürafa, zebra ve deve kuşu gibi hayvanlar vardı. Bahçenin ortasında yapılan suni gölette ise her türden su kuşları ve balıklar yaşamaktaydı. Emîr dinleneceği zaman bu göletin üzerine asılan bir merdiven ile buraya ulaşmaktayd ${ }^{80}$.

\section{Sâmânîler Dönemi}

Sâmânîlerde (819-1005) hayvanat bahçesinin mevcudiyetine dair elimizde şu an için herhangi bir veri bulunmamakla birlikte İbnü'l-Esîr'in bir kaydı dikkate değerdir.

\footnotetext{
${ }^{75}$ Makrîzî 2001, cilt II, s.30-31.

${ }^{76}$ Makrîzî 2001, cilt II, s.10.

${ }^{77}$ Reşid b. Zübeyr 1959, 73-74.

${ }^{78}$ Reşid b. Zübeyr 1959, 76.

${ }^{79}$ Tokuş 2018, 421-453

80 İbn İsfendiyâr 2007, cilt II, s.124-125; Alanoğlu 2020, s.134.
} 
Buna göre Sâmânî Emîri Ebû Nasr Ahmed b. İsmail her gece uyuduğu yerin kapısında nöbetçi olarak bir aslan bağladığı için buraya kimse yaklaşamamaktaydı. Nitekim hizmetçileri aslanı buraya bağlamayı unutunca kölelerden bir grup 23 Cemaziyülahir 301'de (24 Ocak 914) Ebû Nasr Ahmed'i katletmiştir ${ }^{81}$. Bu ifadelerden hayvanat bahçesi ile ilgili bir varsayımda bulunmanın zorlama bir yorum olacağını itiraf etmekle beraber vahşi hayvanların beslendiğine dair bir bilgi olması hasebiyle buraya aktarmanın uygun olabileceğini düşündük.

\section{Karahanlılar Dönemi}

Batı Karahanlı hükümdarı Şemsülmülk Ebü'l-Hasan II. Nasr b. İbrahim'in (1068-1080) hükümdarlığı döneminde icra ettiği bayındırlık faaliyetleri hayvanat bahçeleri açısından güzel bir numunenin ortaya çıkmasına vesile olmuştur. EnNarşahî'nin Târîh-i Buhârâ adlı eserindeki kaydına göre Şemsülmülk II. Nasr, Buhara'da İbrahim Kapısı'nda satın aldığı arazi üzerine bahçeler, bostanlar gibi mesire ve dinlenme alanları yaptırmıştır. Şemsâbâd adını verdiği bu yerde atları için oluşturduğu bir alan inşa ederek buraya Koruk (Goruk/Koru) adını vermiştir. Söz konusu bu alan bir mil uzunluğunda sağlam surlar ile çevrelenmişti. Bir saray ve güvercinler için de bir ev inşa eden emîr, Koruk (Koru) adlı yerde antilop, karaca, tilki ve domuz gibi vahşi hayvanları bulundurduğu bir mahal tahsis ettirmiştir. Burada bulunan hayvanların kaçmasını önlemek içinde alanın çevresine yüksek bir duvar örülmüştür. Ancak bu yapı Şemsülmülk II. Nasr'dan sonra Ahmed Han zamanında tahrip olmuştur ${ }^{82}$.

\section{Gazneliler Dönemi}

Gazneli hükümdarlarının da eğlenmek ve dinlenmek gayesi ile avcılığa ihtimam gösterdikleri bilinmektedir. Gaznelilerin avlanmak için pars ve köpek gibi hayvanları kullandıkları kaydedilmektedir ${ }^{83}$. Nitekim Gazneli Mahmud ile Karahanlı hükümdarı Yusuf Kadir Han arasında 1025'te gerçekleşen Semerkant görüşmesinde Gazneli Mahmud'un Yusuf Kadir Han'a hediye olarak kartal, kerkenez ve av köpekleri gönderilmesini emrettiği söylenmektedir ${ }^{84}$. Av hayvanların barınma ve beslenmesinin yanı sıra Gaznelilerin askerî ve sosyal hayatın birçok alanında ilk defa fil kullanan Türk-İslâm devletlerinden biri olduğu anlaşılmaktadır ${ }^{85}$. Sebüktegin döneminden itibaren fillerden istifade etmeye başlayan ${ }^{86}$ Gazneliler, sayıları 1670'e kadar çıkan fillerin bakımları için filci (pilbân) adlı çoğunlukla Hint asıllı görevliler tayin etmişlerdir ${ }^{87}$. Bu bilgilerden Gaznelilerin av hayvanlarının ve fillerin barınmaları için özel mahaller inşa ettiklerini ileri sürmek mümkündür.

\footnotetext{
${ }^{81}$ İbnü'l-Esîr 1991, cilt VIII, s.69.

82 en-Narşahî 2013, 43-44; Duman 2013, 264; Turan 2009, 189.

${ }^{83}$ Beyhakî 2019, 469.

${ }^{84}$ Akçay 2015, 124.

${ }^{85}$ Merçil 2007, 8; Piyadeoğlu 2014, 67-89.

86 el-Cûzcânî 2015, 27.

${ }^{87}$ Beyhakî 2019, 230, 533.
} 


\section{Ömer TOKUŞ}

\section{Selçuklular Dönemi}

Bu başlık altında Orta Asya'dan Anadolu’ya kadar uzanan geniş bir coğrafyaya hâkim olan Büyük Selçuklu Devleti ve Türkiye Selçuklu Devleti'nde hayvanat bahçelerinin varlığına dair bazı tespitler yapılmaya çalışılacaktır. Hiç şüphesiz mevcut kaynaklar ve bilgiler doğrultusunda Büyük Selçuklu Devleti'nde hayvanat bahçelerinin varlığına dair -bazı istisnalar olmakla beraber- kesin bilgiler bulunmamakla beraber sultanların av merakı için hayvan ihtiyacı ve takdim edilen hediyeler içinde bulunan hayvanların barınması ve beslenmesi için özel mekânların tahsis edilmesinin zaruriyet kesp ettiğini söyleyebiliriz. Göçebe yaşam tarzının bir gereği olarak Selçuklular ava önem vermiş ve av hayvanlarının bakımı ve av işlerinin organizasyonu için Emîr-i Şikâr (Emîr-i Sayd), Bâzdâr ve Sayyad gibi görevliler tayin etmişlerdir ${ }^{88}$. Şüphesiz Büyük Selçuklu Devleti'nin ilk hükümdarı Tuğrul Bey (1040-1063) de bu geleneksel av faaliyetlerini devam ettirmiş ve avdan sonra da ziyafetler vermeyi adet edinmiştir ${ }^{89}$. Özellikle sürek avı askeri açıdan bir egzersiz, spor ve eğlence olarak görüldüğünden büyük ilgi görmüştür. Bu cümleden Büyük Selçuklu Devleti'nin ikinci hükümdarı Alp Arslan'ın (1063-1072) hayati öneme sahip olan Malazgirt Savaşı öncesinde ava çıktığı ve son olarak Bizans imparatorunu esir aldığında yanında doğan ve av köpeği bulundurduğu kaydedilmektedir ${ }^{90}$.

Ava düşkünlüğü ile bilinen hükümdarlardan biri de Melikşah’tır (1072-1092) ${ }^{91}$. Bu özelliğinden dolayı Ebû Tâhir Hatunî’ye günümüze ulaşmayan Şikâr-nâme adlı bir eser yazdırmıştır ${ }^{92}$. Eserini Türkiye Selçuklu hükümdarı I. Gıyaseddin Keyhüsrev’e (1205-1211) takdim eden Râvendî, Ebû Tâhir Hâtûnî’nin eserini gördüğünü kaydetmektedir. Öte yandan Râvendî İsfahan'1 merkez yapan Melikşah'ın şehirde bahçelerden müteşekkil çok sayıda yapı inşa ettiğini söylemektedir ${ }^{93}$. Melikşah'ın ava merakından dolayı tabi devletler gönderdikleri hediyelerde başta av hayvanları olmak üzere değişik türden hayvanlara yer vermekteydiler. Gazneli sultanı İbrâhim b. Me'sûd (1059-1099) Melikşah ile barış anlaşması yapmak gayesiyle Mihter Reşid (Mihtar Rashid) başkanlığında bir elçilik heyeti göndermiştir. Bu heyet ile sultana "develere yüklenmiş güzel ve klymetli elbiseler, Shabar ve Lamgan, Kamar ve Nugh gibi Gazne'nin etrafindaki mintıkalardan elde edilen 100 eşek yükü fil armudu, atlar, merkepler, sı̆̆ıllar, maymun, bir dişi fil, bir çift deve kuşu, bir çift tavus kuşu, bir çift papağan, bir çift beyaz keçi ve bir çift siyah keçi ile Kur'an'l ezberden okuyan Sharak adında bir kuş türü" takdim dilmiştir ${ }^{94}$. Söz konusu hediyeler içinde bulunan hayvanların beslenme ve barınma ihtiyaçlarının karşılanması için özel yapıların -

\footnotetext{
${ }^{88}$ Turan 1998a, 27-28; Merçil 2011, 127, 129, 130.

${ }^{89}$ Nizamülmülk 2013, 89.

${ }^{90}$ Hacigökmen 2012, 27.

${ }^{91}$ Râvendî 1999, cilt I, s.128-129; Hamdullah Müstevfî-yi Kazvinî 2018, 351.

92 Turan 1998b, 221-222.

${ }^{93}$ Râvendî, 1999, cilt I, s.128-129.

${ }^{94}$ Bosworth 1977, 54; Redford 2008, 114, dipnot 228; Paydaş 2013, 461-462
} 
kaynaklarda belirtilmemekle beraber- mevcudiyetinin ihtimal dâhilinde olduğunu söyleyebiliriz.

Bozkır yaşam tarzının etkisiyle Türkiye Selçuklu Devleti hükümdarlarının da av ve avcılık konusunda ilgili oldukları görülmektedir. Şüphesiz bu ilgi avcılık için kullanılan ve avlanan hayvanlara yönelik bir temayül başlatmıştır. Haçlı birlikleri 1189'da (III. Haçlı Seferi esnasında) Konya önlerine ulaştıklarında burada yabani hayvanların barındığı sultana ait hayvanat bahçesi olduğu düşünülen etrafı duvarla örülü bir meydanın ele geçirildiği kaydedilmektedir ${ }^{95}$. Bu, Türkiye Selçuklu Devleti'nde hayvanat bahçelerine dair ilk kayıt olması hasebiyle önemlidir. II. Kılıç Arslan'ın (1155-1192) ölümünden sonra yerine geçen oğlu I. Giyaseddin Keyhüsrev'in (11921196/1205-1211) de ava meraklı olduğu bilinmektedir ${ }^{96}$. Onu takiben Selçuklu tahtına oturan I. İzzeddin Keykavus (1211-1220), Sis seferi dönüşünde Kayseri’ye ulaştığında Ermeni Leon'dan hediye olarak değerli hediyeler ile birlikte bir doğan ve şahin almıştır ${ }^{97}$.

I. İzzeddin Keykavus'un vefatından sonra yerine geçen kardeşi I. Alâeddin Keykubad (1220-1237) da av tutkusundan dolayı şikarhâne (avhane) adı verilen mekânlar inşa etmiştir ${ }^{98}$. Alanya'da Selçuklu bahçeleri ile ilgili yapılan çalışmalar sonucunda burada bulunan yüksek duvarlarla çevrili mahallerin, avcılık ve bahçecilik için kullanıldığını göstermektedir ${ }^{99}$. Alanya dışında Konya ve Beyşehir Gölü kıyısında bulunan Kubadâbâd saraylarında balık, tavus kuşu, güvercin, ördek, kuğu, turna, balıkçıl, ayı, geyik, tavşan, tilki, muflon, yaban geyiği, kurt, aslan, at, tazı, çalıkuşu gibi hayvan tasvirleri avlanan hayvanların çeşitliliğine işaret etmektedir ${ }^{100}$. Beyşehir Gölü'nün batı kıyısında bulunan Kubadâbâd sarayı I. Alâeddin Keykubad'ın talimatı doğrultusunda av emiri ve mimar olan Sadeddin Köpek tarafından yaptırılmıştır ${ }^{101}$. Avlâk olarak kullanılan bu sahalarda yırtıcı kuşların yanı sıra çita ve pars gibi hayvanlar da bulundurulmuştur ${ }^{102}$.

Selçuklu Devleti döneminde hayvanat bahçelerine dair tespit edebildiğimiz ikinci önemli kayıt Sıbt İbnü'l-Cevzî'ye aittir. Yazarımıza göre II. Gıyaseddin Keyhüsrev'in (1237-1246) köpek ve aslanlar ile oynadığı ve ölümünün de bir aslan tarafından 1sırılarak gerçekleştiği yönündedir ${ }^{103}$. Bu bilgilerden dolayıdır ki Redford, II. Gıyaseddin Keyhüsrev'in hayvanat bahçesindeki bir hayvan tarafından 1sırıldığını ileri sürmektedir ${ }^{104}$. Bunların yanı sıra Müverrih Kiragos da II. Gıyaseddin Keyhüsrev'in Kösedağ Savaşı için harekete geçtiği esnada yanında avlanmak için beslediği vahşi

\footnotetext{
${ }^{95}$ The Crusade of Frederick Barbarossa 2010, 172; Redford 2008, 96.

${ }^{96}$ Hacigökmen 2012, 29-30.

${ }^{97}$ İbn Bibi 2020, 196; Merçil 2018, 143.

${ }^{98}$ Hacıgökmen 2012, 29-30.

${ }^{99}$ Redford 2008, 55-56.

${ }^{100}$ Redford 2008, 65.

101 İbn Bibi 2020, 358-359; Merçil 2011, 127; Uysal 2013, 49.

102 Hacı̈ökmen 2012, 48-49.

${ }^{103}$ Sibt İbnü'l-Cevzî 2013, cilt 15, s.125; Yinanç 2014, 188; Turan 1997, 628.

${ }^{104}$ Redford 2008, 48, 112.
} 


\section{Ömer TOKUŞ}

hayvan, yılan, hatta kedi ve fareyi de sürüklediğini kaydetmektedir ${ }^{105}$. Böylece Türkiye Selçuklu Devleti'nde biri II. Kılıç Arslan diğeri de II. Gıyaseddin Keyhüsrev döneminde olmak üzere iki adet hayvanat bahçesinin bulunduğu anlaşılmaktadır. Ancak I. Alâeddin Keykubad döneminde şikârhâne adı verilen avhânelerin kurulması ve buralarda av için hayvanların barındırılması daha başka hayvanat bahçelerinin varlığına da işaret etmektedir.

\section{SONUÇ}

Hükümdarların ve devlet ricalinin avcılık merakı Ortaçağ İslâm devletlerinde elhayrü'l-vahş (hayrü'l-vuhûş) olarak isimlendirilen hayvanat bahçeleri tarzında yapıların ortaya çıkmasına öncülük ettiğini ifade edebiliriz. Bu yapılar Arap-İslâm devletlerinde hayrü'l-vahş, Türk-İslâm devletlerinde bustân (bortan) şeklinde karşımıza çıkmaktadırlar. İlk örneklerine Emevîler döneminde tesadüf edilen bu mekânlar, Abbâsîler zamanında artan refah, zenginlik ve yayılmacı politikanın durmasına bağlı olarak daha da gelişmiş ve akabinde Abbâsîlerin zayıflaması ile kurulan mahalli devletlere de sirayet etmiştir. Söz konusu mahallerde ilk zamanlarda avlanmada kullanılan doğan, kartal, sungur, akbaba, atmaca, şahin gibi yırtıcı kuşlar ile köpek (sungur, salûkiyye gibi), pars, leopar, çita, tazı gibi hayvanlar barındırılmıştır. Ancak bir süre sonra bu mekânlar daha da genişlemiş ve fil, zürafa, aslan, flamingo, güvercin, keklik, kumru, bülbül, papağan, tavus, geyik, tavşan, koyun, antilop, tilki, domuz, karaca, zebra, yılan ve fare gibi hayvanlar ile su kuşları ve balıklara da ev sahipliği yapmıştır.

Modern anlamda mimarî ve tasarım yönünden bugünkü hayvanat bahçelerine benzer yapılara dair Tolunoğulları ve Bâvendîlerde olmak üzere iki önemli örnek öne çıkmaktadır. Tolunoğulları emîrlerinden Humâreveyh ile Taberistân hâkimi Hüsâmüddevle'nin bina ettikleri hayvanat bahçelerinde farklı türden kuş, kara ve su hayvanlarının barındırıldığı görülmektedir. Bu hayvanların beslenme ve barınmaları için de özel görevlilerin tayin edildiği anlaşılmaktadır. Söz konusu hayvanat bahçelerinin hayvan tedarikinin avlanma ve hediyeler ile sağlandığı kaydedilmektedir. Sonuç olarak Ortaçağ Müslüman devletlerinde evcil ve yabani hayvanların bir araya getirildiği bu tarzda özel mekânların hükümdar ve emirlerin dinlenme ve eğlenmesine yönelik inşa edildikleri söylenebilir. Böylece Ortaçağ Müslüman coğrafyasında hayvan türlerinin coğrafî dağılımını tespit edebilmek de mümkün olabilmektedir.

\footnotetext{
${ }^{105}$ Müverrih Kiragos 2009, 51.
} 


\section{KAYNAKLAR}

Abdulbaki $2007 \quad$ Ahmed Abdulbaki, Asımetü'd-Devleti'l-Arabiyye fì Ahdi'lAbbâsiyyîn Sâmerrâ, c. I, Beyrut.

Agibolava ve Donskoy 2017

Ye. Agibolava - G. Donskoy, Ortaçă̆ Tarihi, çev. Çağdaş Sümer, İstanbul.

Ağırakça 1998

Ahsen 2019

Akçay 2015

Altınay 2006

Aykaç 1999

Bayrakdar 1998

Beyhakî 2019

Bosworth 1977

Bozkurt 2003

Câhiz 1966

Demirci 2009

Duman 2013

Ebü'l-Ferec 1987

Ahmet Ağırakça, "Humâreveyh b. Ahmed b. Tolun", DİA, c. XVIII, İstanbul, s. 348-349.

Muhammed Manazir Ahsen, Abbasiler Döneminde Sosyal Hayat 170-289 Hicri/786-902 Miladi, çev. Mehmet Emin Şen, Ankara.

Filiz Akçay, Eb̂̂u Saîd Abdulhay Dahhâk b. Mahmûd Gerdîzî̀nin "Zeynü'l-Ahbar" adlı Eserinin Tâhirîler, Saffârîler, Sâmânîler ve Gaznelîler İle İlgili Bölümlerinin Tercümesi ve Değerlendirmesi, (Ordu Üniversitesi Sosyal Bilimler Enstitüsü Basılmamış Yüksek Lisans Tezi), Ordu.

Ramazan Altınay, Emevilerde Günlük Yaşam, Ankara.

Mehmet Aykaç, "İbn Hinbâze”, DİA, c. XX, İstanbul, s. 70-71. Mehmet Bayrakdar, "Hayvan", DIA, c. XVII, İstanbul, s. 8592.

Ebu'l-Fazl Muhammed b. Hüseyin, Târîh-i Beyhakî, trc. Necati Lügal, Ankara.

Clifford Edmund Bosworth, The Later Ghaznavids: Splendour and Decay The Dynasty in Afghanistan and North India 10401158, Edinburgh.

Nahide Bozkurt, "Mehdî-billâh", DİA, c. XXVIII, İstanbul, s. 377-379.

Câhiz, Kitâbu'l-Hayevân, c. IV, thk. Abdüsselam Muhammed Harun, Kahire.

Mustafa Demirci, "Sâmerrâ", DİA, c. XXXVI, İstanbul, s. 7071.

Abdullah Duman, Nerşahînin Târîh-u Buhârâsı (İnceleme ve Tercüme), İstanbul.

Ebü'l-Ferec, Abu'l-Farac Tarihi, c. I, çev. Ömer Rıza Doğrul, Ankara.

Ebü'l-Ferec el-İsfahânî t.y.

Ebü'l-Ferec el-İsfahânî, el-Agânî, c. XI, thk. Semir Cabir, Beyrut.

ed-Dûrî 1991

el-Belâzürî 1996
Abdülazîz ed-Dûrî , "Bağdat", DİA, c. IV, İstanbul, s. 425-433. el-Belâzürî , Cümel min Ensâbi’l-Eşrâf, c. IX, thk. Süheyl Zekkar-Reyyâd Zirikli, Dârü'l-Fikr, Beyrut. 


\section{Ömer TOKUŞ}

el-Belevî t.y.
el-Cevherî 1987
el-Cûzcânî 2015

el-Ezherî 2001

el-Ferâhîdî t.y.

el-Halidî 2010

el-Himyerî 1999

el-Yafiî 1997

Emin 2012

en-Narşahî 2013

Erkoçoğlu 2017

es-Sâmerrâî 2018

es-Sanavberî 1998

et-Taberî t.y.

Hacıgökmen 2012

Hadad 2009

Hasan t.y.

Hatîb el-Bağdâdî 2015

Hilâl es-Sâbî t.y.

İbn Abdirabbih 2021
Abdullah b. Muhammed el-Belevî, Sîretü Ahmed b. Tolun, thk. Muhammed Kürd Ali, Kahire.

İsmail b. Hammâd el-Cevherî, Tâcü'l-Luga ve Sihâhu'lArabiyye, c. II, thk. Ahmed Abdulgafur Atar, Beyrut.

Minhâc-i Sirâc el-Cûzcânî, Tabakât-ı Nâsırî Gazneliler, Selçuklular, Atabeglikler ve Hârezmşâhlar, Tercüme ve Notlar: Erkan Göksu, Ankara,

Muhammed b. Ahmed el-Ezherî, Tehzîbü'l-Luga, c. V, thk. Muhammed Avd Mer'ab, Beyrut.

Halil b. Ahmed el-Ferâhîdî, Kitâbü'l-'Ayn, c. III, thk. Mehdi el-Mahzûmî-İbrahim es-Sâmerrâ'i, Beyrut.

Ahmed el-Halidî, el-Mudun ve Asâri'l-İslâmiyye fíl-'Alem, Amman.

Neşvân el-Himyerî, Şemsü'l- 'Ulûm ve Devâ'ü Kelâmi'l- 'Arab mine'l-Külûm, c. III, thk. Hüseyin b. Abdullah el-ÖmerîMutahhar b. Ali el-İryânî-Yusuf Muhammed Abdullah, Beyrut. el-Yafîi, Mirâtü'l-cenân ve ibretü'l-yakzân fî ma'rifeti mâ yu'teberu min havâdisi'z-zaman, c. IV, thk. Halil el-Mansur, Beyrut.

Ahmed Emin, Faydu'l-Hâtir, c. VI, Hindâvî, Kahire. en-Narşahî , Târîh-i Buhârâ, çev. Erkan Göksu, Ankara.

Fatih Erkoçoğlu, "İmar Faaliyetleri”, Emeviler Dönemi Bilim, Kültür ve Sanat Hayatı, ed. İrfan Aycan, Ankara, s. 205-295.

Mecid Mülûk es-Sâmerrâî, Sürre Men Re'a el-Âsımetu'lArabiyyeti'l-íslâmiyye, Ammân.

es-Sanavberî, Dîvânu's-Sanavberî, thk. İhsan Abbas, Beyrut.

et-Taberî, Târîhu't-Taberî, c. VIII, thk. Muhammed Ebü'l-Fazl İbrahim, Kahire.

Mehmet Ali Hacıgökmen, Türkiye Selçuklularında Avcılık, Konya.

Nayif Adil Yusuf Hadad, “İmâretü'l-Kusûri'l-Emeviyye fî Bilâdi'ş-Şâm: Dirâsetu Tahlîliyye fi'l-Husûsiyye", Mecelletü'lImarât li-buhûsi'l-hendesiyye, c. XIV, sy. 1, s. 1-8.

Hasan İbrahim Hasan, Siyasi-Dini-Kültürel-Sosyal İslâm Tarihi, c. 2/3, çev. Heyet, İstanbul.

Hatîb el-Bağdâdî, Târîhu Medîneti's-Selâm, c. I, thk. Beşar Avvâd Ma'ruf, Tunus.

Hilâl es-Sâbî, RusûmuDâri'l-Hilâfe, thk. Mîha'ilAvvâd, Beyrut.

İbn Abdirabbih, el-İkdü'l-Ferîd, c. I, çev. Musa Kazım Yılmaz, Ankara. 
İbn Bibi $2020 \quad$ İbn Bibi, el-Evâmirü'l-Alâ'iyye fi'l-Umûri'l-Alâ'iyye Selçuknâme, çev. Mürsel Öztürk, Ankara.

İbn Dureyd 1987 İbn Dureyd, Cemheretu'l-Luga, c. I, thk. Remzi Münir elBa'lebekî, Beyrut.

İbn Dürüsteveyh 1998 İbn Dürüsteveyh, Tashîhu'l-Fasîh ve Şerhihi, thk. Muhammed Bedevî el-Mahtûn, Kahire.

İbn Hallikân t.y. İbn Hallikân, Vefeyâtu'l-A'yân ve Enbâ'i Ebnâ'i'z-Zamân, c. III, thk. İhsan Abbas, Beyrut.

İbn Hişâm el-Lahmî 2003 İbn Hişâm el-Lahmî, el-Medhal ila Takvîmi'l-Lisân, thk. Hatim Salih ed-Dâmin, Beyrut.

İbn İsfendiyâr 2007 İbn İsfendiyâr, Târîh-i Taberistân, c. II, tsh. Abbas İkbal Aştiyani, Tahran. Türkçe trc. Ali Alanoğlu, İbn Isfendiyâr'ın Târîh-i Taberistân Adlı Eseri Bağlamında Bâvendî Hanedanı (Tercüme ve Değerlendirme), Bingöl Üniversitesi Sosyal Bilimler Enstitüsü Yüksek Lisans Tezi, Bingöl 2020, s. 134.

İbn Kesîr 1995 İbn Kesîr, el-Bidâye ve'n-Nihâye, c. XI, çev. Mehmet Keskin, İstanbul.

İbn Manzûr 1414 İbn Manzûr, Lisânu'l- 'Arab, IV, Dâru Sâdr, Beyrut.

İbn Miskeveyh 1998 İbn Miskeveyh, Tecâribü'l-Ümem ve te'âkibü'l-himem, c. V, thk. Ebü'l-Kâsım İmâmî, Tahran.

İbnü'l-Adîm t.y. I İbnü'l-Adîm, Buğyetu't-taleb fì tarihi Haleb, c. I, thk. Süheyl Zekkâr, Beyrut t.y.

İbnü'l-Cevzî 2012 İbnü’l-Cevzî, Muntazam fî Târîhi'l-Mülûk ve'l-Ümem, c. XIII, thk. Muhammed Abdulkadir Ata-Mustafa Abdulkadir Ata, Beyrut.

İbnü'l-Esîr 1991 İbnü'l-Esîr, el-Kâmil fi’t-Târih Tercümesi, c. VIII, çev. Ahmet Ağırkaça, İstanbul.

İbnü't-Tıktaka 2016 İbnü't-Tıktaka, el-Fahrî (Devlet İdaresi, Halifeler, Vezirleri Tarihi 632-1258), çev. Ramazan Şeşen, İstanbul.

Kazvinî 2018 Hamdullah Müstevfî-yi Kazvinî, Târih-i Güzide, çev. Müsel Öztürk, Ankara.

Makkarî 1968 Makkarî, Nefhu't-Tîbmin Gasni'l-Endülüs er-Ratîb, c. I, thk. İhsan Abbas, Beyrut.

Makrîzî 1998 Makrîzî, Kitâbu'l-Mevâ'iz ve'l-'itibârbi-Zikri'l-Hitat ve'l-'Asar, c. II, thk. Halil el-Mansûr, Beyrut.

Makrîzî 1998 Makrîzî, Kitâbu'l-Mevâ'iz ve'l-'Itibâr bi-Zikri'l-Hitat ve'l-'Asar, c. II, thk. Halil el-Mansûr, Beyrut.

Makrîzî 2001 Makrîzî, Itti' âzü'l-hünefâ bi-ahbâri'l-E'immeti'l-Fâtımiyyîn elHulefâ, c. I-II, thk. Muhammed Abdulkadir Ahmed Ata, Beyrut.

Mazaherî 1972 Ali Mazaherî, Ortaçağda Müslümanların Yaşayışları, çev. Bahriye Üçok, İstanbul. 


\section{Ömer TOKUŞ}

Merçil 2007

Merçil 2011

Merçil 2018

Me'sûdî 2005

Mez 2014

Müverrih Kiragos 2009 Müverrih Kiragos, Ermeni Müverrihlerine Göre Moğollar, çev. Gürsoy Solmaz, İstanbul.

Nizamülmülk 2013

Nüveyrî 2004

Özaydın 1991a

Özaydın 1991b

Özkuyumcu 2012

Paydaş 2013

Piyadeoğlu 2014

Râvendî 1999

Redford 2008

Reşid b. Zübeyr 1959

Sıbt İbnü'l-Cevzî 2013 Sibt İbnü'l-Cevzî, Mirâtu'z-Zaman fî Târîhi'l-A 'yân, c. 15, thk. Kamil Selman el-Cebûrî, Beyrut.

Strange 1897

Şeşen 1993

Erdoğan Merçil, Gazneliler Devleti Tarihi, İstanbul.

Erdoğan Merçil, Selçuklular'da Saraylar ve Saray Teşkilatı, İstanbul.

Erdoğan Merçil, "Selçuklular'da Av", Selçuk Üniversitesi Selçuklu Araştırmaları Dergisi, sy. 8, Konya, s. 136-146.

Me'sûdî, Murûcu'z-Zeheb ve Me'adini'l-Cevher, c. III-IV, thk. Muhammed Hişam en-Na'san-AbdulmecidTu'me Halebî, Beyrut.

Adam Mez, Onuncu Yüzyılda İslâm Medeniyeti, çev. Salih Şaban, İstanbul.

Nizamülmülk, Siyâset-nâme, çev. Mehmet Altay Köymen, Ankara.

Nüveyrî, Nihâyetü'l-Ereb fî Fünûni'l-Edeb, c. IV, thk. MüfidKamhiye vd., Beyrut.

Abdülkerim Özaydın, “Av”, DİA, c. IV, İstanbul, s. 101-104.

Abdülkerim Özaydın, "Azîz-billâh”, DİA, c. IV, İstanbul, s. 346.

Nadir Özkuyumcu, “Tolunoğulları”, DİA, c. XLI, İstanbul, s. 233-236.

Kazım Paydaş, "Bilge Bir Hükümdar Gazneli Sultan İbrahim b. Mesud (450-492/1059-1099)", International Journal of Social Science (JASSS), c. 6, sy. 5. Mayıs 2013, s. 455-475.

C. Piyadeoğlu, "Gazneliler ve Büyük Selçuklular'da Filin Kullanılmasına Dair Bazı Tespitler”, XI. Milli Türkoloji Kongresi Bildiriler Kitabı (11-13 Kasım), c. II, İstanbul, s. 6789.

Râvendî, Râhat-üs-Sudûr ve Âyet-üs-Sürûr, c. I, çev. Ahmed Ateş, Ankara.

Scott Redford, Anadolu Selçuklu Bahçeleri, çev. Serdar Alper, İstanbul.

Reşid b. Zübeyr, Kitâbü'z-Zehâ'ir ve't-tuhef, thk. Muhammed Hamidullah, Kuveyt.

Guy Le Strange, "A Greek Embassy to Baghdad in 917 A. D.", Journal of the Great Britain and Ireland, c. 29, sy. 1, s. 35-45.

Ramazan Şeşen, "Dârülhilâfe", DİA, c. VIII, İstanbul, s. 538539.

The Crusade of Frederick Barbarossa 2010 
The Crusade of Frederick Barbarossa The History of the Expedition of the Emperor Frederick and Related Texts, İngilizce çev. G. A. Loud, Farnham.

Tokuş 2018 Ömer Tokuş, "Taberistân Dağlarının Melikleri "Bâvendîler" 45-750/665-1349", Tarihin Peşinde-Uluslararası Tarih ve Sosyal Araştırmalar Dergisi, c. 10, sy. 20, s. 421-453.

Tokuş 2020 Ömer Tokuş, Başlangıçtan Mirdâsîlerin Sonuna Kadar Bilâdü'ş-Şâm'da Müslüman-Bizans Münasebetleri, Ankara.

Tûkân 1981 Fevvâz Ahmed Tûkân, "el-Hadâ'iku'l-Hayevân fî̀ Zamanî'lEmeviyyin", el-Havliyâtu'l-Eseriyye el-Arabiyye es-Sûriyye, c. XXXI, Dımaşk, s. 40-46.

Turan 1997 Osman Turan "Keyhüsrev II”, $\dot{I} A$, c. VI, Eskişehir.

Turan 1998a Osman Turan, Türkiye Selçukluları Hakkında Resmi Vesikalar, Ankara.

Turan 1998b Osman Turan, Selçuklular Târihi ve Türk-İslâm Medeniyeti, İstanbul.

Turan 2009 Osman Turan, Selçuklu Tarihi ve Türk-İslam Medeniyeti, İstanbul.

Uysal 2013 Zekiye Uysal, Kubad-Abad Sarayında Selçuklu Cam Sanatı, Ankara.

Ya'kûbî 2002 Ya'kûbî, Ülkeler Kitabı, çev. Murat Ağarı, İstanbul.

Yâkût el-Hamevî 1995 Yâkût el-Hamevî, Mucemü'l-Büldân, c. II, Beyrut.

Y1ldı 1988a Hakkı Dursun Yıldız, “Abdurrahman I”, DİA, c. I, İstanbul, s. 147-150.

Yıldız 1988b Hakk1 Dursun Yıldız, “Abdurrahman III”, DİA, c. I, İstanbul, s. 152-155.

Y1lmaz 2005 Metin Yılmaz, "Müslüman Arap Toplumunda Av Hayatı ve Siyasî Hayata Yansımaları: Abbâsî Örneği”, EKEV Akademi Dergisi, c. 9, sy. 22, (Kış 2005), Erzurum, s. 257-258.

Yinanç 2014 Mükrimin Halil Yinanç, Türkiye Tarihi Selçuklular Devri, II. cilt, haz. Refet Yinanç, Ankara.

Zehebî 1983 Siyeru A'lâmu'n-Nübelâ, c. XV, thk. Şuayb el-Arna'ûd-İbrahim ez-Zeybek, Beyrut.

Zeydan 2012 Corci Zeydan, İslâm Uygarlıkları Tarihi, c. II, çev. Nejdet Gök, İstanbul. 


\section{Ömer TOKUŞ}

\section{SUMMARY}

In medieval Muslim states, zoos were named as Hayru'l-Wahsh (hayru'l-vuhush), derived from concepts such as al-Khayr, al-Ha'ir, al-Khayir, or their plural, al-Hiyar, AlHayran, and al-Havran. But in the later period, especially in the Karakhanid and Seljuk States, the word bostan (bustan) began to be used instead of these words. Attempts for the emergence of zoos in medieval Muslim states began with the Caliph, ruler or dignitaries engaged in hunting. Hunting, which is seen as a means of earning a livelihood and living off for ordinary people, is also conceived as fun and timewasting for rulers and dignitaries.

It is noted that the Prophet encouraged hunting as a combat exercise and sport, and Caliphate Omar advised to organize horse races in Kufe for similar purposes. Hunting has become a hobby due to the interest of the caliphs along with the Umayyads, and therefore some work has begun to shelter the animals used in hunting. Yezîd b. Muawiyah, the second caliph of the Umayyads, is known to feed some animals such as birds of prey, cheetahs, and hunting dogs. Indeed, it is claimed that the first zoo was built adjacent to the palaces Kasru'l-Hayri'l-Garbî and Kasru'l-Hayri'ş-Şarkî, built by the Umayyad caliph Hishâm b. Abdulmalik. Hishâm and his successor, Velîd b. Yezîd, had an interest in horse racing, leading to the emergence of racecourses called al-Halbe, where a large number of horses were housed and raced.

Hunting continued to be one of the favorite exercises of the Abbasids and caliphs, and specially bred animals began to be used for this purpose. These tendencies of the Abbasid caliphs can be explained by their interest in sports, increasing wealth, establishing close relations with the Iranians, and pursuing a non-expansionist policy. The first Abbasid caliph Abu'l-Abbas es-Seffah fed hawks, falcon, dogs, and pars for hunting. During the reign of Harun Rashid, racecourses were built where horse races were held. The first information about hayrü'l-vahş, which is described as a zoo in the Abbasids, belongs to the Emin period. Accordingly, Emin, who went to hayrü'l-vahş to have fun and relax, drank wine with music here.

It is mentioned that when Caliph Mutasim built Samerra in 836, the place was surrounded by high walls, in which deer, wild donkeys, rabbits, and sheep roamed. It is recorded that the number of animals in a new zoo built in parallel with the increase in public works activities during the Mutasim period reached two thousand. Caliph Muqtadir also gave Byzantine envoys who arrived in 917 a tour of the zoo in Baghdad. It is noted that the caliphs, as well as important statesmen, also have private zoos.

In addition to the Abbasids, the ruler of the Umayyad State of Andalusia, Abdurrahman I, built a botanical garden and zoo in Rusafe near Kurtuba, and Abdurrahman III built a botanical garden and zoo on behalf of his concubine Zahra. The most concrete example that can be given about zoos in modern understanding belongs to the Tolunids period. Shortly after Ahmad bin Tolun's son Humarawayh took the throne, he embarked on an arrangement reminiscent of modern-day zoos. Humarawayh, who transformed the square of the palace built by his father into a large garden, arranged the space in question as a botanical garden and zoo. This garden was home to different species of birds such as doves, flamingo, and Abyssinian hen. 
Abu'l-Fazl Ibn al-Furat, i.e. Ibn Hinzabe who was one of the İhshidi statesmen and briefly served as vizier after the Fatimids took Egypt also had a hobby such as feeding different kinds of animals. It is mentioned that Ibnu'furat, who was briefly the vizier of the Fatimids and was released in 973 after Muiz's arrival in Egypt, had a garden where he collected snakes and vermin. He displayed the snakes and reptiles in baskets in a marble courtyard and assigned special servants to care for them.

It is also mentioned that Husamuddevle Ardashir, one of the Ispehbediyah rulers of Bavendi, has also a notable Zoo in connection with our topic. It is suggested that in the middle of the palace named Badhane and located in Devletabad, there is a large pool and around it, there are pigeons, nightingales, doves, parrots, and other bird species, and a cellar with bait was built to provide the needs of the animals.

Two records of the existence of Zoos stand out in the Seljuks, who dominated a large area from Central Asia to the Sea of Marmara. The first of them belongs to the periods of Kilıç Arslan II and the second of them belongs to the periods of Giyaseddin Kayhusrav II. In addition, the hunting grounds built during the time of Alaaddin Kaykubad I also provide indirect information about the existence of Zoos. Finally, there are the records of such structures in the Ayyubid, Altınorda, and Mamluk States. 